\title{
ANTICOAGULANT ACTIVITY OF EQUINE FOLLICULAR FLUID
}

\author{
J. E. STANGROOM* AND R. DE G. WEEVERS $\dagger$ \\ Department of Veterinary Clinical Studies, School of \\ Veterinary Medicine, Cambridge \\ (Received 1st Fuly 1961)
}

\begin{abstract}
Summary. The present investigation was undertaken in order to find out why the follicular fluid of the mare does not clot. Although equine follicular fluid was found to contain less fibrinogen than normal blood plasma, there was sufficient present to form a clot after the addition of excess thrombin. The absence of clotting appears to be due to the presence of an active anticoagulant in the follicular fluid. Its properties have been investigated in some detail, and it appears to be very similar to heparin.

This anticoagulant may be of considerable physiological significance at the time of ovulation, when it would prevent the ovum becoming trapped in a plasma clot.
\end{abstract}

\section{INTRODUCTION}

It has been known for many years that crude ovarian extracts contain anticoagulant activity (Conradi, 1902). More recently, it has been observed that follicular fluid itself seldom clots (Zachariae \& Jensen, 1958; Short, 1960). This absence of clotting could be of considerable physiological significance, since a clot formed around the ovum when the follicle ruptures might well hinder passage of the ovum down the oviduct, and impede sperm penetration and fertilization.

The composition of follicular fluid has been shown by several investigators (Lutwak-Mann, 1954; Caravaglios \& Cilotti, 1957; Zachariae \& Jensen, 1958) to be similar to that of blood serum, and several workers have put forward theories as to why it does not clot. Zachariae (1958) suggested that this could be due to a deficiency of fibrinogen. Rinaldi (1956), on the other hand, thought that there might be a heparinoid present in follicular fluid; this would be in accord with the observations of Zachariae \& Jensen (1958), who noted that follicular fluid contains an appreciable amount of sulphate mucopolysaccharides.

\section{Follicular fluid}

\section{MATERIALS AND METHODS}

This was obtained from the ovaries of mares by puncturing the Graafian follicles. Tests showed that for a given animal anticoagulant activity seemed

* Present address: Department of Chemistry, Sheffield University.

$\uparrow$ Present address: Zoological Laboratory, Downing Street, Cambridge. 
to be independent of follicle size, so collection was not controlled closely in relation to follicle size. The fluid was collected immediately following slaughter, with a large-bore hypodermic needle, and as far as possible blood was excluded. The fluid was then centrifuged and the supernatant decanted into small glass bottles which were stored at $-15^{\circ} \mathrm{G}$. In later experiments involving comparison between animals, it was found necessary to take more stringent precautions to avoid changes in $\mathrm{pH}$. It was noticed that follicular fluid kept at room temperature became steadily more alkaline at the rate of about $0.2 \mathrm{pH}$ units per hour; fluid left in the follicle became acid somewhat more slowly. In order to overcome this difficulty, immediately the fluid had been collected from a given animal the collecting bottle was put into dry ice and acetone, and kept there until needed.

\section{Plasma}

One hundred millilitres of blood were taken from the jugular vein of a horse with a siliconized cannula. It was collected into a polythene bottle containing $4 \mathrm{ml}$ Wintrobe's solution ( $3 \mathrm{~g}$ potassium oxalate $+3 \mathrm{~g}$ ammonium oxalate in $100 \mathrm{ml}$ water). The blood was then centrifuged at approximately $2500 \mathrm{~g}$ in nylon tubes for $30 \mathrm{~min}$. The plasma was decanted and stored at $-15^{\circ} \mathrm{C}$ in small glass bottles.

For the thromboplastin-generation test, blood was obtained as above, but it was collected into a $3.8 \%(\mathrm{w} / \mathrm{v})$ solution of trisodium citrate, at the rate of one volume of citrate solution for nine volumes of blood. It was then centrifuged in cellulose-acetate tubes at approximately $3000 \mathrm{~g}$ for $30 \mathrm{~min}$ in a refrigerated centrifuge at $2^{\circ} \mathrm{C}$. The plasma was decanted and stored at $-15^{\circ} \mathrm{C}$ in small glass bottles.

\section{Calcium}

A solution of $0.025 \mathrm{~m}$ calcium chloride was made up in distilled water.

\section{Thromboplastin}

A suspension of $0.5 \mathrm{~g}$ of solid horse-brain extract (prepared according to the procedure of Quick (1938), and stored in evacuated tubes at $5^{\circ} \mathrm{C}$ ) was made up in $10 \mathrm{ml}$ of normal saline solution as required each day. This suspension was kept at $50^{\circ} \mathrm{C}$ for $12 \mathrm{~min}$, then cooled and the solid residue centrifuged and rejected.

\section{Thrombin and fibrinogen}

These were extracted from horse plasma by the methods of Jaques (1943). For some experiments, solutions of thrombin prepared from ampoules supplied by S. Maw \& Sons Ltd were used.

\section{Cephalin (platelet substitute)}

This was made from solid horse-brain extract by the method of Bell \& Alton (1954).

\section{Buffered saline solution}

This was made up as follows: $13.6 \mathrm{ml} 0.1 \mathrm{~N}$ hydrochloric acid $+25 \mathrm{ml}$ $1.34 \%(\mathrm{w} / \mathrm{v})$ glyoxaline in water $+0.85 \mathrm{~g}$ sodium chloride $+61.4 \mathrm{ml}$ water. 
Estimation of fibrinogen concentration

\section{METHODS}

Follicular fluid was treated with a large excess of thrombin. The reaction mixtures were incubated for $1 \mathrm{hr}$ at $37^{\circ} \mathrm{C}$, and then the fibrin clot was filtered off in a weighed sinter-glass crucible, washed with normal saline solution, distilled water and acetone and dried at $110^{\circ} \mathrm{C}$. The clot was then weighed, and compared with the weight of a clot produced from plasma by the same method.

\section{One-stage prothrombin test (Quick, 1938)}

This test involves the measurement of the time taken for the first threads of fibrin to appear after the addition of calcium chloride solution to a mixture of equal volumes of plasma and thromboplastin extract. The test is carried out in a water-bath at $37^{\circ} \mathrm{C}$ with constant shaking. A similar technique was used to measure thrombin times, but calcium solutions were omitted and the reaction was started by the addition of purified thrombin solution to the mixture under investigation.

\section{Troo-stage prothrombin test (Herbert, 1940)}

In this test, which was carried out at $37^{\circ} \mathrm{C}, 2 \mathrm{ml}$ plasma and $2 \mathrm{ml}$ thromboplastin extract were mixed with $2 \mathrm{ml}$ of either saline solution, as in the control experiment, or follicular fluid diluted to $20 \%$ with saline solution in the test experiment. Two millilitres of $0.025 \mathrm{~m}$ calcium chloride in $0.1 \mathrm{~m}$ glycyl glycine buffer at $\mathrm{pH} 7 \cdot 2$ were then added and simultaneously a stop-watch was started. At known intervals after this, $0 \cdot 1-\mathrm{ml}$ portions were withdrawn from the reaction mixture and added to $0 \cdot 1-\mathrm{ml}$ aliquots of fibrinogen solution. The clotting times of the latter were plotted against the time at which the portion of the reaction mixture was added to the fibrinogen.

\section{Thromboplastin-generation test (Biggs ङ̈ Douglas, 1953a)}

In this test, the variation in the concentration of blood thromboplastin in the incubation mixture under investigation is followed by periodically withdrawing $0 \cdot 1-\mathrm{ml}$ aliquots, and adding these together with $0.1 \mathrm{ml}$ calcium chloride solution to tubes containing $0.1 \mathrm{ml}$ plasma. For the purposes of this investigation, where accurate data on the concentration of thromboplastin were not required, the thromboplastin concentrations were calculated from the clotting times, with the data of Biggs \& Macfarlane (1957).

The incubation mixture used was as follows, the reagents being added in this order:

$0.3 \mathrm{ml}$ of a 1:5 dilution of plasma in a buffered saline solution, the plasma having previously been treated with aluminium hydroxide.

$0.3 \mathrm{ml}$ of a $1: 10$ dilution of serum in buffered saline solution,

$0.3 \mathrm{ml}$ cephalin suspension (Bell \& Alton, 1954),

0.05 toluidine blue solution (test), or buffered saline solution (control),

0.05 follicular fluid (test), or buffered saline solution (control),

$0.3 \mathrm{ml}$ calcium chloride solution.

Timing for the withdrawal of aliquots for thromboplastin estimation was started on the addition of the calcium chloride. 


\section{Dialysis}

Twenty millilitres of the fluid to be dialysed was placed in a section of cellulose-dialysis tubing (No. 4465-A.2, Arthur H. Thomas) and dialysed against $0.8 \%$ saline solution for $12 \mathrm{hr}$ at room temperature. Normally, 21 of dialysis medium were used; this was stirred continuously throughout the dialysis.

\section{Electrophoresis}

The procedure recommended by Reinits (1953) for the paper electrophoresis of mucopolysaccharides was used. Initially the experiments were carried out with $0 \cdot 1 \mathrm{M}$ phosphate, buffered to $\mathrm{pH} 6 \cdot 7$, but better separation was obtained later at $\mathrm{pH} 7 \cdot 3$. A potential gradient of $12.5 \mathrm{v} / \mathrm{cm}$ was applied for approximately $12 \mathrm{hr}$ per run. By the use of a broad strip of highly absorbent paper (Whatman $3 \mathrm{MM}$ ), it was found possible to investigate the anti-thrombin activity of the eluates from 2-cm wide strips directly. At the end of each run, the paper was dried at $60^{\circ} \mathrm{C}$ and cut into strips which were drip eluted, by the technique of Sanger \& Tuppy (1951). The elution was usually complete after 4 to $5 \mathrm{hr}$. The process could be speeded up by lightly spraying the strips with saline solution at the start of the elution. A blank paper was run at the same time, and blank strips were eluted in order to correct for any variations in ionic strength along the length of the paper strip; the inhibition of fibrin formation obtained from the paper blanks was then subtracted from the inhibition found in the test run with follicular fluid.

TABLE 1

GOMPARISON OF FIBRINOGEN CONCENTRATIONS IN FOLLIGULAR FLUID AND PLASMA

\begin{tabular}{|c|c|}
\hline Reaction mixture & Dry weight of fibrin $(\mathrm{mg})$ \\
\hline $\begin{array}{l}2 \mathrm{ml} \text { follicular fluid }+ \\
8 \mathrm{ml} \text { thrombin stock solution }\end{array}$ & $2 \cdot 8$ \\
\hline $\begin{array}{l}1 \mathrm{ml} \text { follicular fluid }+ \\
1 \mathrm{ml} \text { plasma }+ \\
8 \mathrm{ml} \text { thrombin stock solution }\end{array}$ & $65 \cdot 0$ \\
\hline $\begin{array}{l}2 \mathrm{ml} \text { plasma }+ \\
8 \mathrm{ml} \text { thrombin stock solution }\end{array}$ & $112 \cdot 4$ \\
\hline
\end{tabular}

\section{$p H$ determinations}

These were carried out with a Pye 'Universal' $\mathrm{pH}$ meter.

\section{RESULTS}

CONCENTRATION OF FIBRINOGEN

It will be seen from Table 1 that the fibrinogen level in follicular fluid is about one-fortieth of that in plasma, but this relative fibrinogen deficiency still does not prevent follicular fluid from forming a clot when excess thrombin is added. 
ACTIVE ANTICOAGULANT ACTIVITY

It was demonstrated that follicular fluid is able to inhibit clotting of plasma in Quick's test. Table 2 shows that this inhibition is directly proportional to the amount of follicular fluid present. Caution is needed in interpreting these results, however, since the clotting times of these samples are greater than the maximum values for which the one-stage test is regarded as reliable.

TABLE 2

EFFEGT OF DILUTION ON ANTIGOAGULANT PROPERTIES OF FOLLIGULAR FLUID

\begin{tabular}{c|c}
\hline $\begin{array}{c}\text { Amount of follicular fuid added }(\mathrm{ml}) \\
\text { (made up to } \begin{array}{c}1 \text { ml with normal saline } \\
\text { solution) }\end{array}\end{array}$ & $\begin{array}{c}\text { Mean clotting time (sec) } \\
\pm S . D .\end{array}$ \\
\hline 0 & $30 \pm 4$ \\
0.02 & $40 \pm 4$ \\
0.03 & $43 \pm 9$ \\
0.04 & $53 \pm 11$ \\
0.05 & $58 \pm 6$ \\
0.06 & $59 \pm 16$ \\
$0 \cdot 07$ & $77 \pm 17$ \\
0.10 & \\
\hline
\end{tabular}

Reaction mixture: $0.1 \mathrm{ml}$ saline solution +follicular fluid, $0.1 \mathrm{ml}$ thromboplastin extract, $0.1 \mathrm{ml} \mathrm{m} / 40$ calcium-chloride solution, $0.1 \mathrm{ml}$ plasma.

MODE OF AGTION OF THE ANTICOAGULANT

Having thus obtained evidence for the presence of an active anticoagulant in follicular fluid, it was necessary to investigate the stage in clotting mechanism at which it might act. In the present work, attention was confined to the effect of follicular fluid upon those stages following the production of thromboplastin. A preliminary investigation was therefore carried out, with the two-stage prothrombin test.

The results of the two-stage test are shown in Text-fig. 1. It will be seen that the time at which thrombin activity is maximal is little changed by the addition of follicular fluid, whereas the actual level of thrombin activity is depressed. This is similar to the type of inhibition shown for heparinoids by Biggs \& Douglas (1953b). On the basis of the theoretical curves derived by these workers for the two-stage test, the results presented here demonstrate marked inhibition of the thrombin-catalysed system by $20 \%$ follicular fluid. There is no definite evidence of anti-thromboplastin activity, although these results do not preclude this possibility. It should be noted that either an anti-prothrombin or an anti-thrombin could produce the inhibition of the thrombin-catalysed system demonstrated in Text-fig. 2.

The anticoagulant was therefore investigated further by incubating $0.2 \mathrm{ml}$ of stock thrombin solution with $0.1 \mathrm{ml}$ fibrinogen solution and either saline solution or $20 \%$ follicular fluid in saline solution. The resultant clotting times are recorded in Table 3 and demonstrate marked inhibition of clotting by follicular fluid; this could be due to either anti-thrombin, anti-fibrinogen or

$\mathrm{D}^{*}$ 


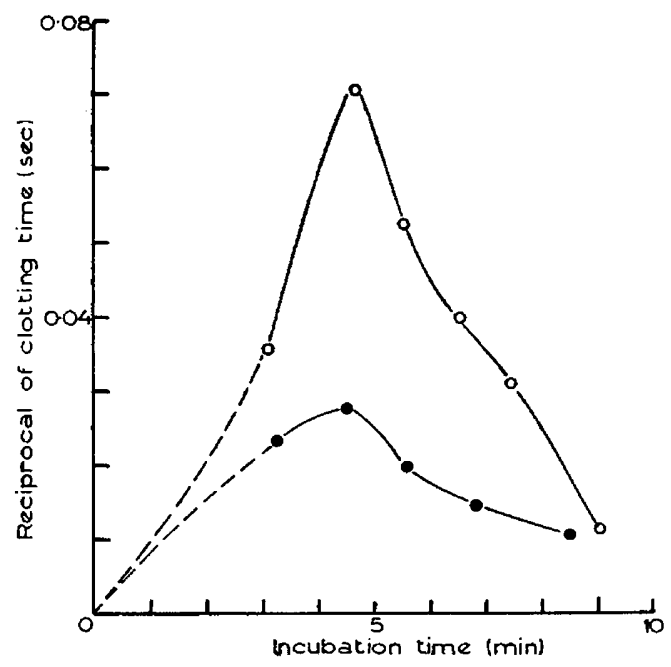

TEXT-FIG. 1. Two-stage prothrombin curves. Dotted lines indicate area in which readings were impossible due to uncontracted clot and long clotting times. O- O Control. 0.1-M glycyl glycine, $\mathrm{pH}$ 7.2.

- $20 \%$ follicular fluid in $0.1 \mathrm{~m}$ glycyl glycine.

fibrinolytic activity. The last of these possibilities was eliminated by the observation that incubation of follicular fluid for long periods with fibrin clots produced no observable fibrinolysis.

TABLE 3

EFFECT OF FOLLIGULAR FLUID UPON THE CLOTTING TIME OF PURIFIED FIBRINOGEN AND THROMBIN

\begin{tabular}{c|c|c}
\hline Reaction mixture & $\begin{array}{c}\text { Thrombin concentrate } \\
\% \text { of stock solution })\end{array}$ & $\begin{array}{c}\text { Clotting time (sec) } \\
\text { Mean } \pm \text { S.D. (No. } \\
\text { observations in parentheses })\end{array}$ \\
\hline Test & 100 & $\begin{array}{l}17 \pm 2(7) \\
92 \pm 28(3)\end{array}$ \\
$\begin{array}{c}\text { FF* +fibrinogen + thrombin } \\
(0 \cdot 1 \mathrm{ml} \text { of each) }\end{array}$ & 50 & $16 \pm 1(7)$ \\
\hline $\begin{array}{c}\text { Control } \\
(0 \cdot 1 \mathrm{ml} \text { of each) }\end{array}$ & 100 & $15 \pm 0 \cdot 3(3)$ \\
\hline
\end{tabular}

* Follicular fluid diluted to $20 \%$ with normal saline solution.

ANTI-THROMBIN ACTIVITY

The effects of prolonged incubation of thrombin and fibrinogen with follicular fluid were then tested. Equal volumes of thrombin solution and $20 \%$ follicular fluid were incubated together and it was found that the clotting times of $0 \cdot 1-\mathrm{ml}$ samples withdrawn at intervals and added to $0 \cdot 1-\mathrm{ml}$ portions of fibrinogen rose steadily as shown in Table 4 . This effect is similar to the action of heparin + co-factor on thrombin, as reported by Lyttleton (1954); however, the precise comparison of time scales and concentrations is somewhat difficult. This is therefore evidence for anti-thrombin activity in follicular fluid. 
It was found that incubation of fibrinogen with follicular fluid for upwards of 30 min produces no progressive change in anticoagulant activity, tested as above. There is thus no evidence for any additional anticoagulant action on any of the other stages after thromboplastin formation.

TABLE 4

PROGRESSIVE INACTIVATION OF THROMBIN

\begin{tabular}{c|c}
\hline $\begin{array}{c}\text { Incubation time } \\
\text { (sec) }\end{array}$ & $\begin{array}{c}\text { Mean clotting time of five samples } \pm \text { S.D. } \\
\text { (sec) }\end{array}$ \\
\hline 0 & $25 \pm 3$ \\
5 & $31 \pm 4$ \\
10 & $37 \pm 5$ \\
15 & $45 \pm 3$ \\
20 & $56 \pm 8$ \\
\hline
\end{tabular}

A volume of $0 \cdot 1 \mathrm{ml}$ stock solution of thrombin was incubated for varying periods of time with $0 \cdot 1 \mathrm{ml}$ follicular fluid, then $0.1 \mathrm{ml}$ stock solution of fibrinogen added, and clotting timed from this addition.

\section{Effect of $p H$ on thrombin inhibition}

\section{MECHANYSM OF THROMBIN INACTIVATION}

Text-fig. 2 shows the influence of $\mathrm{pH}$ on the anti-thrombin activity of follicular fluid. Curve A was obtained by adding increasing amounts of $0.1 \mathrm{~m}$ potassium hydroxide to $23 \%$ follicular fluid in $0.1 \mathrm{~m}$ potassium dihydrogen phosphate; sufficient untreated follicular fluid was added at the same time to maintain its concentration in the reaction mixture at $23 \%$. At selected $\mathrm{pH}$ values, $0 \cdot 1-\mathrm{ml}$ samples were withdrawn, mixed with $0 \cdot 1-\mathrm{ml}$ portions of stock fibrinogen solution and the clotting times determined. The control curve was obtained in the same way, except that saline solution was substituted for follicular fluid. Curve B shows the effect of adding $0.1 \mathrm{~m}$ potassium dihydrogen phosphate gradually to $23 \%$ follicular fluid in $0.1 \mathrm{~m}$ potassium hydroxide, the latter having been kept at room temperature for $4 \mathrm{hr}$. Apparently the anticoagulant is slowly destroyed after having been kept so long at this high $\mathrm{pH}$.

There can be no doubt that the anticoagulant activity of follicular fluid is sensitive to $\mathrm{pH}$, being increased as the solution becomes more alkaline and completely lost below $\mathrm{pH} 6 \cdot 0$.

\section{CHEMICAL NATURE OF THE ANTICOAGULANT}

The foregoing experiments have demonstrated that follicular fluid contains an anti-thrombin, whose action is sensitive to changes in $\mathrm{pH}$. Further tests were therefore undertaken in order to determine the chemical properties of this substance.

\section{Effect of dialysis}

It was found that dialysis removed some but not all of the anticoagulant activity from follicular fluid. This is consistent with the report of Walton (1955) that heparin is composed of a range of substances, rather than a single substance. The results obtained here could therefore be explained by the loss of lowermolecular-weight components, assuming that the anticoagulant is of a similar nature to heparin. 


\section{Effect of heating}

The dialysis experiment suggests that the anticoagulant may contain a fraction of high molecular weight. The effect of heating was therefore tried. After heating to various temperatures, all coagulated material was spun down at $15,000 \mathrm{rev} / \mathrm{min}$. Table 5 shows that some anticoagulant activity remained in the supernatant after heating to $90^{\circ} \mathrm{C}$ for $20 \mathrm{~min}$, and the activity of a saline extract of the precipitated proteins suggests that some of the activity that is lost on heating may be by adsorption. Thus, a considerable proportion of the anticoagulant is thermostable. The significance of these results is discussed in a later section (see 'Effects of protamine sulphate and toluidine blue on anti-thrombin').

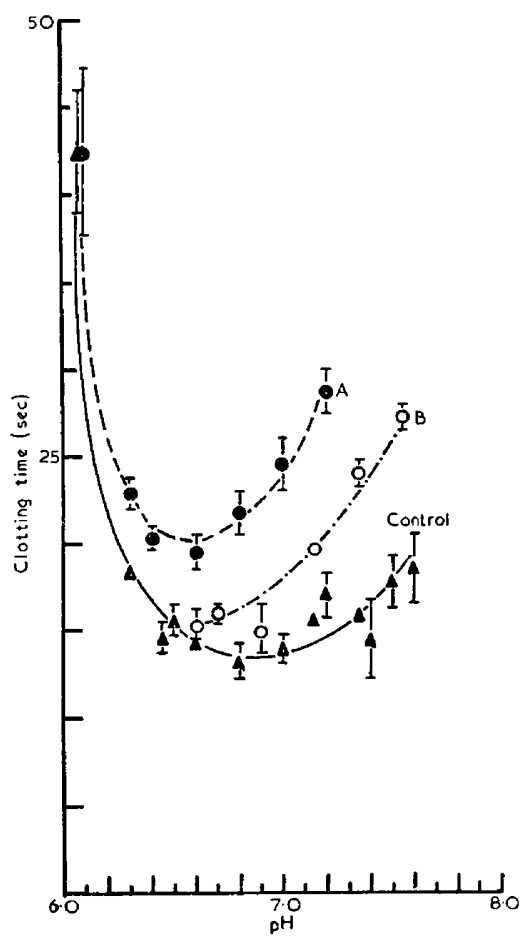

TEXT-FIG. 2. Effect of $p H$ on inhibition of thrombin by follicular fluid.

$\mathrm{A}=0.1 \mathrm{M}$ potassium hydroxide added to $23 \%$ follicular fluid in $0.1 \mathrm{M}$ potassium dihydrogen phosphate.

$\mathbf{B}=0.1 \mathrm{M}$ potassium dihydrogen phosphate added to $23 \%$ follicular fluid in $0.1 \mathrm{M}$ potassium hydroxide.

Vertical lines indicate s.D.

A-A Control-saline solution.

Effect of ether on the anticoagulant

It was found that ether fails to extract any anticoagulant activity from follicular fluid, and the residue retains its activity. The former observation indicates that the inhibitor is probably non-lipoidal; the latter has an important bearing on the identity of the anti-thrombin in relation to Fell's scheme (Fell, Ivanovic, Johnson \& Seegers, 1954; see Table 7). 
Incubation of follicular fluid with hyaluronidase

The effect of a high concentration of testicular hyaluronidase (Rondase, Evans; 3000 i.u. $/ \mathrm{ml}$ ) on a $20 \%$ dilution of follicular fluid in saline solution was tested. No reduction of anti-thrombin activity took place over a period of an hour. This rules out most of the common mucopolysaccharides; however, heparin, which is a mucopolysaccharide, is not attacked by hyaluronidase since it inhibits this enzyme (Mathews \& Dorfman, 1955).

TABLE 5

EFFEGT OF HEATING UPON FOLLICULAR-FLUID ANTI-THROMBIN

\begin{tabular}{|c|c|}
\hline Substance under test & $\begin{array}{c}\text { Mean thrombin time } \pm \text { S.D. }(\mathrm{sec}) \\
(\mathcal{N} \text { o. observations in parentheses })\end{array}$ \\
\hline $\begin{array}{l}\text { Control (saline solution) } \\
\text { Untreated follicular fluid ( } 20 \% \text { in saline } \\
\text { solution) } \\
20 \% \text { Follicular fluid in saline solution, } \\
\text { heated to } 75^{\circ} \text { C for } 20 \text { min } \\
20 \% \text { Follicular fluid in saline solution, } \\
\text { heated to } 90^{\circ} \mathrm{C} \text { for } 20 \text { min } \\
\text { *Saline-solution extract of precipitate } \\
\text { from follicular fluid heated to } 90^{\circ} \mathrm{C} \text { for } \\
20 \text { min }\end{array}$ & $\begin{array}{l}9 \cdot 9 \pm 0 \cdot 9(4) \\
19 \cdot 8 \pm 1 \cdot 6(3) \\
19 \cdot 5 \pm 0 \cdot 6(4) \\
16 \cdot 7 \pm 2 \cdot 9(4) \\
26 \cdot 6 \pm 2 \cdot 5(4) \text { undiluted } \\
19 \cdot 5 \pm 2 \cdot 0(4) \text { diluted }\end{array}$ \\
\hline
\end{tabular}

After the heating of the follicular fluid, the precipitate was centrifuged off and the supernatant diluted 1:5 with normal saline solution. Untreated follicular fluid was diluted in the same way.

* The protein precipitate from follicular fluid heated to $90^{\circ} \mathrm{C}$ was homogenized in an amount of saline solution equal to the original volume of follicular fluid. This was centrifuged and the supernatant used undiluted and diluted $1: 5$ with normal saline solution.

\section{Electrophoresis}

Paper electrophoresis of follicular fluid at $\mathrm{pH} 7 \cdot 3$ showed some apparent migration of anti-thrombin activity in two bands moving in opposite directions.

EFFECTS OF PROTAMINE SULPHATE AND TOLUIDINE BLUE ON ANTI-THROMBIN The action of heparin is neutralized by protamine sulphate (Chargaff \& Olson, 1937-38) and toluidine blue (Walton, 1955). Accordingly, the effect of these substances on the anti-thrombin of follicular fluid was tested both before and after heat treatment. The following results were obtained:

1. The follicular-fluid anti-thrombin was antagonized and eventually completely suppressed by increasing concentrations of toluidine blue and protamine sulphate.

2. Excess protamine sulphate reduced the clotting time to less than the control value. This is almost certainly an artefact due to the effect of the highly charged protamine sulphate molecule upon the protein in this system, since the clots formed under these conditions had a different appearance from those formed normally. Toluidine blue did not have this effect.

3. Whereas the anti-thrombin activity of heated follicular fluid was less susceptible to antagonism by protamine sulphate than that of unheated follicular fluid, exactly the reverse was true of toluidine blue. The reason for this is not known. 
Antagonism by toluidine blue is perhaps the most definitive test available for a heparinoid anticoagulant, and the effect of toluidine blue upon the follicular-fluid anticoagulant was therefore investigated in more detail. This was done in two ways.

Text-fig. 3 shows the effect on the clotting time of the addition of a gradually increasing amount of toluidine blue to a system containing constant amounts of thrombin, fibrinogen and follicular-fluid anticoagulant. In this experiment, the toluidine blue was made up in buffered saline solution to $240 \mathrm{mg} / 100 \mathrm{ml}$ as the stock solution; the thrombin (Maw \& Sons) was made up in buffered saline solution to approximately $30 \mathrm{units} / \mathrm{ml}$. The fibrinogen used was that actually present in follicular fluid; the end-point was very clear since the first threads of fibrin formed took up the toluidine blue selectively, and could then

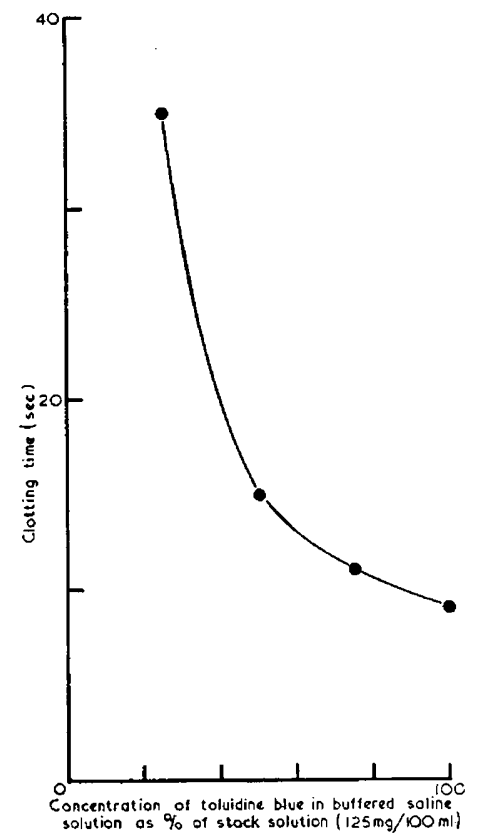

TEXT-FIG. 3. Effect of toluidine blue on follicular fluid anti-thrombin under carefully controlled conditions.

be seen easily. The procedure adopted was to add $0.1 \mathrm{ml}$ of the appropriate dilution of toluidine blue to $0.1 \mathrm{ml}$ of the standard thrombin solution. Precisely $1 \mathrm{~min}$ after this, $0 \cdot 1 \mathrm{ml}$ follicular fluid was added and a stop-watch was started to record the clotting time. The results in Text-fig. 4 show quite conclusively that increasing concentrations of toluidine blue progressively destroy the antithrombin activity of follicular fluid.

Text-fig. 4 shows the effect of adding follicular fluid and toluidine blue, both singly and together, on the thromboplastin-generation test. This test is very sensitive to heparin; the replacement of the $0.05 \mathrm{ml}$ of follicular fluid added to the reaction mixture by $0.05 \mathrm{ml}$ of a solution of heparin in buffered saline solution containing $0.5 \mathrm{units} / \mathrm{ml}$ caused complete inhibition of clotting in all the samples. An aliquot of $0.05 \mathrm{ml}$ of a solution containing 0.05 units of 
heparin/ml produced quite a measurable response, but not as great as that produced by $0.5 \mathrm{ml}$ of follicular fluid. Further, the type of inhibition produced by the added heparin is very similar to that produced by follicular fluid, in that all percentages of thromboplastin are lowered, but the time of peak concentration is not altered.

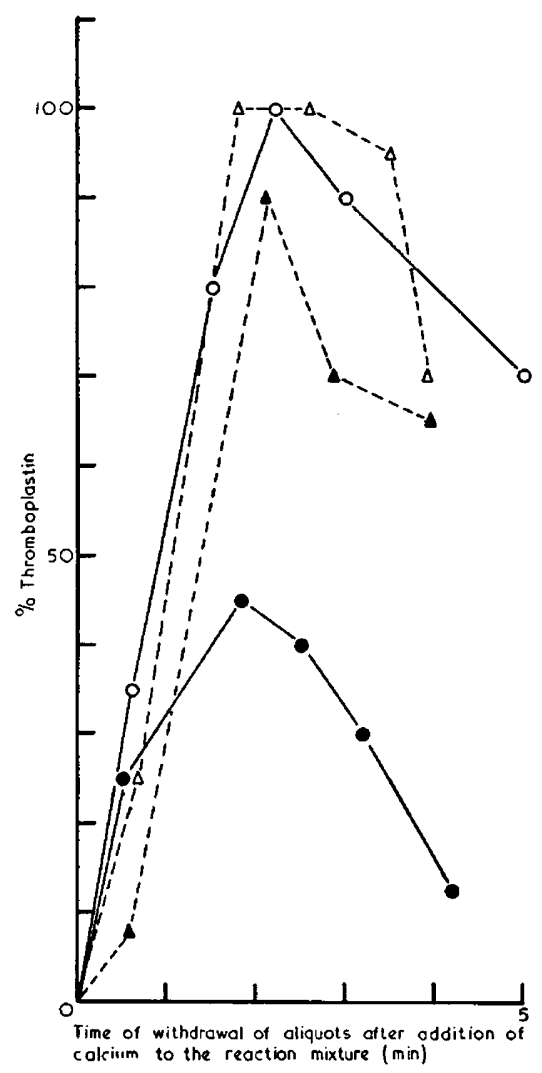

TEXT-FIG. 4. Effect of follicular fluid and toluidine blue on the thromboplastin-generation test.

$0 \longrightarrow 0$ Saline solution.

$\Delta-.-\Delta$ Toluidine blue + saline solution.

A.... - Toluidine blue + follicular fluid.

- Saline solution + follicular fluid.

It will be seen from Text-fig. 4 that the addition of a volume of toluidine blue solution $(240 \mathrm{mg} / 100 \mathrm{ml})$ equal to the volume of follicular fluid added produces almost complete correction of the clotting defect due to the latter. This, in conjunction with the results shown in Text-fig. 3, shows quite unequivocally that the follicular-fluid anticoagulant is suppressed completely by toluidine blue, and thus in this respect it behaves very like heparin.

VARIATIONS OF ANTI-THROMBIN ACTIVITY THROUGHOUT THE OESTROUS CYGLE Table 6 shows the results of a series of experiments undertaken to determine the anti-thrombin activity of follicular fluid obtained from mares slaughtered at 
various stages of the oestrous cycle. The stage of the oestrous cycle was determined by the macroscopic appearance of both ovaries on sectioning. By this means, it was possible to place any given specimen into one of three phases of the cycle, namely oestrous, early luteal or mid-to-late luteal. The $\mathrm{pH}$ of the sample was measured at the same time as the sample was tested for anticoagulant activity. To determine the anticoagulant activity, each sample was diluted with $0 \cdot 1 \mathrm{~m}$ phosphate buffer and made up to a $20 \%$ solution at the same $\mathrm{pH}$. It was then mixed with fibrinogen and thrombin in the usual way. The difference between the clotting times thus obtained and the clotting time of a reagent blank in which phosphate buffer was substituted for follicular fluid is shown in Table 6. The $\mathrm{pH}$ of the follicular fluid stayed approximately

TABLE 6

VARIATION IN ANTICOAGULANT AGTIVITY OF FOLLICULAR FLUID DURING THE OESTROUS GYGLE

\begin{tabular}{c|c|c}
\hline Stage in cycle & $\begin{array}{c}\text { Animal } \\
\text { No. }\end{array}$ & $\begin{array}{c}\text { Mean anticoagulant activity } \pm \text { S.E. } \\
\text { (No. observations in parentheses) }\end{array}$ \\
\hline Oestrous & 1 & $37 \cdot 2 \pm 8 \cdot 0(4)$ \\
& 2 & $4 \cdot 8 \pm 0 \cdot 8(3)$ \\
\hline \multirow{3}{*}{ Early luteal } & 3 & $4 \cdot 6 \pm 1 \cdot 9(6)$ \\
& 4 & $2 \cdot 7 \pm 0 \cdot 8(3)$ \\
& 5 & $26 \cdot 4 \pm 2 \cdot 2(3)$ \\
\hline \multirow{3}{*}{ Mid-to-late luteal } & 6 & $8 \cdot 7 \pm 1 \cdot 6(3)$ \\
& 7 & $23 \cdot 8 \pm 7 \cdot 0(6)$ \\
& 8 & $29 \cdot 2 \pm 3 \cdot 6(3)$ \\
\hline
\end{tabular}

* Anticoagulant activity is expressed as the difference in clotting time (sec) between (1) a test mixture of $0.1 \mathrm{ml}$ follicular fluid diluted $1: 5$ with $0.1 \mathrm{M}$ phosphate buffer of the same $\mathrm{pH}+0.1 \mathrm{ml}$ fibrinogen $+0.1 \mathrm{ml}$ thrombin, and (2) a control mixture of $0.1 \mathrm{ml}$ of the same phosphate buffer + $0.1 \mathrm{ml}$ fibrinogen $+0.1 \mathrm{ml}$ thrombin.

constant throughout the cycle at about $7 \cdot 4$. There were no obvious changes in the anticoagulant activity during the cycle.

\section{DISCUSSION}

The results obtained with the two-stage prothrombin test, with toluidine blue and with protamine sulphate, would suggest the presence of a heparinoid. This is in agreement with a suggestion by Rinaldi (1956), and all the other observations seem to be consistent with this hypothesis.

In Table 7, a comparison is made between the follicular-fluid anti-thrombin and the known anti-thrombin properties of heparin. This Table reveals a general similarity between the follicular-fluid anticoagulant and heparin, and the detailed results obtained with toluidine blue antagonism of the anticoagulant indicate that the similarity may be quite close. However, the present study cannot be said to have demonstrated the presence of heparin per se. Such a conclusion would only be possible after the actual isolation and chemical investigation of the active material.

As to the actual concentration of this heparinoid in the follicular fluid, the 
present studies do not give any precise information. However, from the results obtained in the thromboplastin-generation test, it would appear that there is slightly more than 0.05 units heparin equivalent $/ \mathrm{ml}$ in follicular fluid collected from an animal in oestrus.

\section{TABLE 7}

COMPARISON OF SOME OF THE PROPERTIES OF HEPARIN AND THE FOLLICULAR-FLUID ANTI-THROMBIN

\begin{tabular}{|c|c|c|}
\hline & $\begin{array}{l}\text { Follicular-fluid } \\
\text { anti-thrombin }\end{array}$ & $\begin{array}{l}\text { Heparin +heparin co-factor } \\
\quad(\text { anti-thrombin } I I)\end{array}$ \\
\hline Effect of heating & $\begin{array}{l}\text { Anti-thrombin activity much } \\
\text { reduced, but not obliterated }\end{array}$ & $\begin{array}{l}\text { Heparin unharmed, but co-factor } \\
\text { destroyed - some retention of } \\
\text { activity (Fell et al., 1954) }\end{array}$ \\
\hline Effect of extraction with ether & Unchanged & $\begin{array}{l}\text { Doubtful. } \\
\text { Seegers (1954)-unchanged; } \\
\text { Monkhouse \& Clark (1957)- } \\
\text { reduced }\end{array}$ \\
\hline Time course of inhibition & Initially rapid, then slower & $\begin{array}{l}\text { Initially rapid, then slower at high } \\
\text { concentration of heparin } \\
\text { (Lyttleton, 1954) }\end{array}$ \\
\hline Homogeneity & Probably not a single substance & $\begin{array}{l}\text { Not a single substance (Walton, } \\
1955 \text { ) }\end{array}$ \\
\hline $\begin{array}{l}\text { Effects of protamine sulphate } \\
\text { and toluidine blue }\end{array}$ & Antagonized & $\begin{array}{l}\text { Antagonized. } \\
\quad \text { (Chargaff \& Olson, 1937-38) } \\
\text { (Walton, 1955) }\end{array}$ \\
\hline $\begin{array}{l}\text { Influence on thromboplastin- } \\
\text { generation test }\end{array}$ & $\begin{array}{l}\text { Reduces concentrations of throm- } \\
\text { boplastin, without shifting } \\
\text { position of the peak }\end{array}$ & $\begin{array}{l}\text { Reduces concentrations of throm- } \\
\text { boplastin, without shifting posi- } \\
\text { tion of the peak }\end{array}$ \\
\hline
\end{tabular}

\section{ACKNOWLEDGMENTS}

We would like to acknowledge our indebtedness to Dr R. V. Short and Dr T. R. R. Mann of the A.R.C. Unit of Reproductive Physiology \& Biochemistry, and to Professor L. P. Pugh of the Department of Veterinary Clinical Studies, University of Cambridge; without the facilities they put at our disposal this work would not have been possible. Our thanks are also due to Mr E. T. ReesEvans and Mr R. F. Seamark for their assistance. Dr R. K. Archer and Miss J. Spranger of the Animal Health Trust gave us much valuable advice, and helped with the thromboplastin-generation tests. Miss I. Levett was of great assistance in typing the manuscript and preparing all the Text-figs.

\section{REFERENCES}

Bell, W. N. \& Alton, H. G. (1954) A brain extract as a substitute for platelet suspensions in the thromboplastin generation test. Nature, Lond. 174, 880.

Biggs, R. \& Douglas, A. S. (1953a) The thromboplastin generation test. F. clin. Path. 6, 23.

Biggs, R. \& Douglas, A. S. (1953b) The measurement of prothrombin in plasma. A case of prothrombin deficiency. 7. clin. Path. 6, 15.

Biggs, R. \& Macfarlane, R. G. (1957) Human blood coagulation, 2nd edn., p. 103. Blackwell Scientific Publications, Oxford.

Garavaglios, R. \& Gilotti, R. (1957) A study of the proteins in the follicular fluid of the cow. $\mathcal{F}$. Endocrin. 15, 273.

Chargaff, E. \& Olson, K. B. (1937-38) Studies on the chemistry of blood coagulation. VI. Studies on the action of heparin and other anticoagulants. The influence of protamine on the anticoagulant effect in vivo. 7. biol. Chem. 122, 153. 
Conradi, H. (1902) Über die Beziehung der Autolyse zur Blutgerinnung. Beitr. chem. Physiol. Path. $1,136$.

Feli, G., Ivanovic, N., Johnson, S. A. \& Seegers, W. H. (1954) Differentiation of plasma antithrombin activities. Proc. Soc. exp. Biol., N.Y. 85, 199.

HERBERT, F. K. (1940) The estimation of prothrombin in human plasma. Biochem. F. 34, 1554.

JAQues, L. B. (1943) The reducing properties of fibrinogen. Biochem. 7. 37, 344.

Lutwak-Mann, C. (1954) Note on the chemical composition of bovine follicular fluid. f. agric. Sci. 44, 477 .

LytrLEton, J. W. (1954) The antithrombin activity of heparin. Biochem. F. 58, 15.

Mathews, M. B. \& Dorfman, A. (1955) Inhibition of hyaluronidase. Physiol. Rev. 35, 381.

Monkmouse, F. C. \& Clark, D. W. (1957) Further studies on the purification of antithrombin and heparin cofactor. Canad. 7. Biochem. Physiol. 35, 373.

Quick, A. J. (1938) The nature of bleeding in jaundice. 7. Amer. med. Assoc. 110, 1658.

ReINITs, K. G. (1953) The electrophoresis of acid mucopolysaccharides on filter paper. Biochem. $\mathcal{F}$. $53,79$.

Rinaldi, A. (1956) L'attivita eparinicá del plasma durante il ciclo mestruale. Boll. Soc. Ital. Biol. sper. 32, 60 .

SANGER, F. \& TUPpy, H. (1951) The amino acid sequence of the phenyl-alanyl chain of insulin. Biochem. 7. 49, 463.

Sezgers, W. H. (1954) Prothrombin and fibrinogen related to blood clotting mechanisms. Physiol. Rev. 34, 711.

SHort, R. V. (1960) Steroids present in the follicular fluid of the mare. F. Endocrin. 20, 147.

Walton, K. W. (1955) Chemistry and mode of action of heparin and related steroids. Brit. med. Bull. 11, 62 .

ZachariaE, F. (1958) Studies on the mechanism of ovulation. Permeability of the blood-liquor barrier. Acta endocr., Copenhagen, 27, 339.

Zachariae, F. \& JeNSEN, C. E. (1958) Studies on the mechanism of ovulation. Histochemical and physico-chemical investigations on genuine follicular fluid. Acta endocr., Copenhagen, 27, 343.

\section{Note added in proof}

The authors' attention has recently been drawn to a series of papers by Palla, who has similarly demonstrated the presence of a heparin-like anti-coagulant in the follicular fluid of women, sows, cows, bitches and rabbits. He believes that this substance is produced by the granulosa cells of the follicle.

\section{REFERENCE}

Palla, V. (1952) Azione del solfata di protamina sulla sostanza eparinosimile del liquor folliculi. Minerva ginec. (Torino) 4, 164. 